\title{
Mesleki ve Teknik Eğitim Öğretmenlerinin Eğitim Programı Kavramına İlişkin Görüşleri*
}

\author{
The Views of the Teachers on the Concept of Curriculum in Vocational \\ and Technical Education \\ Gülçin TAN-ŞiŞMAN**, Bilgen KERKEZ*** \\ - Geliş Tarihi: 23.01.2019• Kabul Tarihi: 28.03.2019• Yayın Tarihi: 21.06 .2019
}

\begin{abstract}
$\ddot{\mathbf{O} z}$
Bu çalışmanın amacı, mesleki ve teknik eğitim program geliştirme çalışmalarında görev alan öğretmenlerin, eğitim programı kavramına ilişkin görüşlerinin incelenmesidir. Nitel araştırma desenlerinden olgubilim deseni ile yürütülen araştırmaya, Ankara ili merkez ilçelerinde yer alan devlete bağlı mesleki ve teknik eğitim okullarında görev yapan ve aynı zamanda Mesleki ve Teknik Eğitim Genel Müdürlüğü'ne bağlı olarak 2012-2016 yılları arasında program geliştirme komisyonlarında görev almış atölye, laboratuvar ve meslek dersleri öğretmenleri arasından ölçüt örnekleme ve maksimum çeşitlilik örneklemesi ile belirlenen 19 öğretmen katılmıştır. Araştırmacılar tarafından geliştirilen yarı yapılandırılmış bireysel görüşme formu aracılı̆̆ıyla elde edilen veriler, içerik analizi ile çözümlenmiştir. Bulgulara göre, öğretmenlerin tamamına yakınının eğitim programını, eğitim-öğretim faaliyetlerinde yol gösterici rehber olarak tanımladıkları görülmektedir. Bazı öğretmenlerin, eğitim programının öğelerine ilişkin yeterli düzeyde kuramsal bilgiye sahip olmadıkları ve bazı kavramlar arasındaki farkları net olarak ortaya koyamadıkları tespit edilmiştir.
\end{abstract}

Anahtar sözcükler: mesleki ve teknik eğitim, eğitim programı, öğretmenler

Atıf:

Tan-Şişman, G., ve Kerkez, B. (2019). Mesleki ve teknik eğitim öğretmenlerinin eğitim programı kavramına ilişkin görüşleri. Pamukkale Üniversitesi Eğitim Fakültesi Dergisi, 47, 262-286. doi: 10.9779/pauefd.516706

\footnotetext{
* Bu çalışma ikinci yazarın, ilk yazar danışmanlığında yürüttüğü yüksek lisans tez çalışmasının bir bölümünden oluşturulan ve 6. Uluslararası Eğitim Programları ve Öğretim Kongresi’nde sunulan bildirinin genişletilmiş halidir.

** Dr. Öğr. Üyesi, Hacettepe Üniversitesi, Eğitim Fakültesi, gulcintans@gmail.com, ORCID ID: 0000-0002-38066086

*** Milli Eğitim Uzmanı, Mesleki ve Teknik Eğitim Genel Müdürlüğü, bilgentas05@ @otmail.com, ORCID ID: 0000$0002-5124-6030$
} 


\begin{abstract}
The aim of the present study was to investigate the teachers' opinions about the theoretical and practical aspects of curriculum in vocational and technical education. Employing phenomenological research design, the study conducted with totally 19 teachers who took part in the Curriculum Development Commissions in the years between 2012-2016 as well as working at the public vocational-technical high schools located in Ankara. The participants were selected through criterion and maximum variation sampling strategies. The data gathered via the semi-structured interview schedule, were analyzed through content analysis. The findings revealed that the vocational and technical education teachers defined curriculum as a guideline for educational and instructional activities. Although they revealed some awareness about the theoretical and practical issues of curriculum, some of them have inadequate knowledge about the aspects of curriculum.
\end{abstract}

Keywords: vocational and technical education, curriculum, teachers

\title{
Cited:
}

Tan-Şişman, G., \& Kerkez, B. (2019). The views of the teachers on the concept of curriculum in vocational and technical education. Pamukkale Üniversitesi Eğitim Fakültesi Dergisi, 47, 262286. doi: $10.9779 /$ pauefd.516706 


\section{Giriş}

Sosyo-ekonomik kalkınmanın gerçekleşmesinde, ihtiyaç duyulan insan gücüne erişim yollarından birisi kaliteli bir mesleki ve teknik eğitim sistemidir. Mesleki teknik eğitim, bireye ekonomik ve sosyal yaşamın çeşitli sektörlerindeki mesleklere ilişkin bilgi, beceri, yeterlilik, tutum, anlayış kazandırılmasını ve aynı zamanda bireyin iş gücü piyasasındaki etkililiğinin sürdürülebilirliğini amaçlayan bir eğitim sürecidir (Avrupa Eğitim Vakfı [European Training Foundation, [ET], 2005; Avrupa Mesleki ve Teknik Eğitimi Geliştirme Merkezi [European Center for the Development of Vocational Training, [CEDEFOP], 2008; Birleşmiş Milletler Eğitim Bilim ve Kültür Örgütü [The United Nations Educational Scientific and Cultural Organisation, [UNESCO], 1996; Uluslararası Çalışma Örgütü [International Labour Organization [ILO], 2006). Gereksinim duyulan nicelik ve nitelikte meslek elemanının yetiştirilmesi amacına hizmet eden (Mesleki ve Teknik Eğitim Araştırma ve Geliştirme Merkezi [METARGEM], 1997) mesleki ve teknik eğitim toplumsal açıdan, bireylerin sürdürülebilir kalkınma ve ekonomik refahı destekleyici, nitelikli iş gücü olarak istihdama katılabilmesini; bireysel açıdan düşünüldügünde ise bireylerin zihinsel, duygusal, ekonomik ve sosyal gelişimini sağlayabilmesi adına ihtiyaç duyduğu yetkinlikleri kazanarak toplumsal hayatta yerini alabilmesini sağlayan eğitim-öğretim faaliyetlerini kapsamaktadır (Alkan, Doğan ve Sezgin, 1998). Türkiye Mesleki ve Teknik Eğitim Strateji Belgesi ve Eylem Planı'nda (2014, s.18) mesleki ve teknik eğitimin amacı, “...öğrencileri iyi vatandaş olarak yetiştirmenin yanı sıra esnek bir yapı içinde ilgi ve yetenekleri doğrultusunda ortak bir genel kültür verilerek bir üst öğrenime ve/veya iş hayatına hazırlama" olarak ifade edilmiştir.

Ülkelerin ihtiyaç duyduğu birey profiline erişmede, ülke politikasının ve felsefesinin yön verdiği eğitim programları büyük önem arz etmektedir. UNESCO (aktaran Tutkun ve Aksoyalp, 2010) öğrencilerin, sosyo-ekonomik kalkınmayı destekleyecek nitelikte bireyler olarak yetiştirilmesini, 21.yüzyılda program geliştirme çalışmalarının öncelikli amaçlarından biri olarak belirlemiştir. Bu öncelikli amaç, ülkemizde mesleki ve teknik eğitim sisteminde sürdürülen program geliştirme çalışmalarının ve bu çalışmalar neticesinde uygulamaya konulan eğitim programlarının da odak noktasını oluşturmaktadır. Diğer bir ifadeyle, mesleki ve teknik eğitimde sürdürülen program geliştirme çalışmaları, sektör beklentilerine cevap veren, ulusal ve uluslararası bilgi, beceri ve yetkinliklere sahip meslek elemanları yetiştirme amacına ulaşmayı hedeflemektedir (MEGEP, 2014).

Toplumların hedefledikleri ideal insan profiline ulaşmalarında bir yol haritası olarak nitelendirilen (Tan-Şişman ve Karsantık, 2017) eğitim programının geliştirilmesinde ve uygulanmasında öğretmenler büyük rol oynamaktadır. Tekbıyık ve Akdeniz (2008) programın başarılı bir şekilde uygulanabilmesinde öğretmenlerin, program hakkında olumlu tutum geliştirmeleri ve programı kabullenmelerinin gerektiğini ifade etmektedir. Unruh ve Unruh (1984) benzer bir açıklama ile program geliştirme çalışmalarının ürünü olarak ortaya çıkan eğitim programının başarısının öğretmen katılımı, desteği ve iş birliği ile doğru orantılı olduğunu ifade etmektedir. Diğer bir deyişle öğretmenler, eğitim programının “... aktarıcısı olmaktan öte, ... programın her bir öğesinin dinamik ilişkiler bütünü olarak yapılandırıldığının ve bu yol haritasını öğrencilerine, sınıf ortamına ve diğer etmenlere göre düzenlemesi gerektiğinin bilinciyle hareket eden bir farkındalığa sahip olmalıdır" (Tan-Şişman, 2017; s.1303). Bu nedenle öğretmenlerin, program geliştirme ile ilgili tüm aşamalarda sürecin 
ayrılmaz bir parçası olarak yer almaları gerekir (Duman, 2006; Oliva, 2009; Ornstein ve Hunkins, 2004; Yiğit, 2002). Buna rağmen dinamik, döngüsel ve çok boyutlu bir süreç olan program geliştirme çalışmalarının ülkemizdeki uygulamaları incelendiğinde en önemli paydaşlardan biri olan öğretmenlerin genellikle görüş bildirme kapsamında bu sürece dahil edildiği görülmektedir (Milli Eğitim Bakanlığı [MEB], 2017; Yılmaz ve Yiğit, 2011). Ancak mesleki ve teknik eğitim sisteminde, program geliştirme çalışma komisyonlarının ilgili alan öğretmenlerinden oluşturulması ve program geliştirme sürecinin; analiz, tasarlama, uygulama ve değerlendirme olmak üzere belirlenen tüm aşamalarının bu komisyon üyelerince yürütülmesi "Mesleki ve Teknik Öğretim Programları ve Materyalleri Geliştirme Usul ve Esaslarında" (2014) açıkça ifade edilmektedir.

Diğer bir yandan, mesleki ve teknik eğitimde program geliştirme çalışmalarına yönelik alan yazın incelendiğinde, yapılan araştırmaların meslek alanlarına özgü modüler eğitim programlarının ve öğretim materyallerinin, öğretmen ve öğrenci görüşleri çerçevesinde değerlendirildiği görülmektedir (Aktaş, 2012; Arabacıoğlu, 2013; Ata, 2007; Ekşioğlu, 2013; Ergin, 2008; İşoğlu, 2010; Seçilmiş ve Ünlüönen, 2010; Türkeşsiz, 2008). Örneğin Arabacioğlu (2013) tarafından endüstri meslek veya teknik liselerde görev yapan bilişim teknolojisi öğretmenlerinin modüler eğitim programı hakkındaki görüşlerinin ortaya konması amacıyla yapılan araştırmada öğretmenler, programın olumlu yönleri olarak uzmanlaşmaya olanak sağlaması ve grup uygulamalarına vurgu yaparken; ölçme-değerlendirme süreçleri, modül içerikleri, hizmet içi eğitim, öğretim materyallerine ilişkin yaşadıkları sorunları ifade etmişlerdir. Ekşioğlu (2013) tarafından meslek liselerinde uygulanan modüler öğretim programını değerlendirmek ve sorunları belirlemek amacıyla yapılan araştırmada; öğretmenler modüler programın amaçlarının açık, anlaşılır ve davranışsal olarak ifade edilebilir şekilde ve öğrencileri mesleğe hazırlayıcı nitelikte olduğunu belirtirken program içeriğinin öğrenci ihtiyaçlarını karşılamakta yetersiz kaldığını da vurgulamışlardır. Aktaş'ın (2012) metal teknolojisi alanı modüler öğretim programına ilişkin öğretmen görüşlerini belirlemek amacıyla yürüttüğü çalışmada, öğretmenlerin büyük bir kısmında modüler öğretim sisteminin uygulanış1 ile ilgili bilgi eksikliklerinin olduğu sonucuna ulaşılmıştır. Seçilmiş ve Ünlüönen'in (2010) MEGEP kapsamında meslek liselerinde uygulamaya konulan yeterliliğe dayalı modüler programların uygulanabilirliğinin, otelcilik ve turizm meslek liselerindeki uygulamalar kapsamında inceledikleri araştırmalarında; ders bilgi formlarında yer alan öğretim yöntem ve teknikleri, donanım, ölçme değerlendirmeye ve uygulamaya yönelik açıklamalar öğretmenler tarafından tam anlamıyla yeterli bulunmamaktadır. Öğretmenler hazırlanan programlardaki tanımlamaların, içeriklerin ve amaçların gerekli yeterlikleri kazandıracak nitelikte olduğunu düşünürken okullarındaki fiziki donanımın modüler öğretimin uygulaması için yeterli olmadığı görüşündedirler. Ergin (2008) tarafından MEGEP kapsamında geliştirilen Bilişim Teknolojileri alanındaki eğitim programının öğretim sürecindeki mevcut durumu ve karşılaşılan güçlükleri öğretmen görüşleriyle ortaya koymayı amaçlayan araştırmada; öğretmenler, eğitim programında ölçme ve değerlendirme ile ilgili yeterli bilgilendirme olmadığ 1 için zorluk çektiklerini belirtmişlerdir. Türkeşsiz (2008) tarafından MEGEP kapsamında hazırlanan Motorlu Araçlar Teknolojisi alanı eğitim programlarının meslek liselerinde uygulanabilirlik düzeyinin teknik öğretmenler, müdür ve müdür yardımcıları ve öğretim görevlilerinin görüşleri doğrultusunda ortaya konulması amacıyla yapılan araştırmada, katılımcıların programların içeriğinin toplumun ve okulun beklentilerine cevap verebilir nitelikte olması konusunda hemfikir oldukları sonucuna 
ulaşılmıştır. Ata'nın (2007) mesleki eğitimde uygulamaya konan MEGEP projesi kapsamında hazırlanan bilişim teknolojileri alanı eğitim programını öğretmen ve öğrenci görüşleri doğrultusunda incelediği araştırmasında, öğretmenlerin tamamına yakını eğitim programının ögrencileri istihdama hazırlama da yeterli olduğu görüşündedir. Yıldırım ve Şimşek (2001) tarafından, Türkiye'deki mesleki ve teknik eğitim okullarındaki program geliştirme sürecinin etkililiğini değerlendirmek amacıyla yapılan araştırmanın sonuçlarına göre; araştırma kapsamında yer alan mesleki ve teknik eğitim okullarının yarısında program geliştirme sürecine yön veren ihtiyaç değerlendirmesi ile ilgili bir çalışmanın yapılmadığı ortaya çıkmıştır. Araştırma sonuçlarına göre; sektörün gerektirdiği bilgi ve becerinin belirlenmesini amaçlayan ihtiyaç belirleme çalışmalarının yapılmaması ve bu çalışmalara program geliştirme sürecinde yer verilmemesi mesleki ve teknik eğitim programlarının güncelliğini yitirmesine ve öğrenci ve sektörün ihtiyaçları doğrultusunda güncellenmemesine neden olmaktadır. Bu bağlamda, mesleki ve teknik eğitim kurumlarında görev yapan öğretmenlerin eğitim programı kavramına ilişkin görüşlerine odaklanan araştırmalara rastlanılamamıştır.

Mesleki ve teknik eğitimde program geliştirme komisyonlarında görev alan atölye, laboratuvar ve meslek dersleri öğretmenlerinin eğitim programı kavramına ilişkin görüşlerinin incelenmesi amacıyla yürütülen bu çalışmanın, genel anlamda mesleki ve teknik eğitimde program geliştirme çalışmalarına katkı sağlayacağı düşünülmektedir. Bu noktada, çalışmaya katılan mesleki ve teknik eğitim öğretmenlerinin, eğitim programı kavramı hakkında sahip oldukları bilgi, beceri ve farkındalıklarına ilişkin elde edilen derinlemesine ve bütüncül veriler ile öğretmenlik meslek yeterlilikleri kapsamında var olan durumun ortaya konulmasına ş̧ık tutarak; politika yapıcılar, öğretmen eğitimcileri, program geliştirme uzmanları başta olmak üzere tüm ilgili paydaşlara yol gösterici olması beklenmektedir.

$\mathrm{Bu}$ araştırmada, mesleki ve teknik eğitimde program geliştirme çalışmalarında görev alan atölye, laboratuvar ve meslek dersleri öğretmenlerinin eğitim programı kavramına ilişkin görüşlerinin incelenmesi amaçlanmıştır. $\mathrm{Bu}$ amaç doğrultusunda araştırmaya yön veren alt problemler aşağıda sunulmuştur.

Mesleki ve teknik eğitimde program geliştirme çalışmalarında görev alan atölye, laboratuvar ve meslek dersleri öğretmenlerinin

1. eğitim programı kavramına ilişkin tanımları nelerdir?

2. eğitim programının öğelerine yönelik görüşleri nelerdir?

3. eğitim programının işlevlerine yönelik görüşleri nelerdir?

\section{Yöntem}

Mesleki ve teknik eğitimde program geliştirme çalışmalarında görev alan atölye, laboratuvar ve meslek dersleri öğretmenlerinin eğitim programı kavramına ilişkin görüşlerinin incelenmesi amacına yönelik olarak gerçekleştirilen bu araştırma, nitel bir araştırmadır. Nitel araştırmalarda çalışmanın odağındaki olgu, olay veya durumlar kendi bağlamında, katılımcıların yükledikleri anlamlar temelinde yorumlanır (Altunışık, Coşkun, Bayraktaroğlu ve Yıldırım, 2010). Bu araştırmada, mesleki ve teknik eğitimde görev yapmakta olan atölye, laboratuvar ve meslek dersleri öğretmenlerinin, görev yaptıkları program geliştirme komisyonlarında elde ettikleri deneyimler çerçevesinde eğitim programına yönelik görüşlerinin incelenmesi amaçlandığından nitel araştırma desenlerinden olgubilim deseninde yürütülmüştür. Creswell'e (2014) göre 
olgubilim deseninde, araştırmaya konu olan olgular ile ilgili bireylerin deneyimleri ayrıntılı olarak betimlenmektedir.

\section{Çalışma Grubu}

Araştırmanın çalışma grubunu, mesleki ve teknik eğitimde yürütülen program geliştirme çalışmalarında görev alan atölye, laboratuvar ve meslek dersleri öğretmenleri oluşturmaktadır. Çalışma grubu, araştırma konusuyla ilgili zengin bilgi kaynaklarının seçimine izin veren amaçlı örnekleme yöntemlerinden ölçüt örnekleme ve maksimum çeşitlilik örneklemesi kullanılarak belirlenmiştir. Ölçüt örnekleme, önceden belirlenmiş bir dizi ölçütü karşılayan durum veya kişilere odaklanırken; maksimum çeşitlilik örneklemesi ise araştırmada yer alacak bireylerin çeşitliliğinin maksimum düzeyde yansıtılmasını amaçlayan örnekleme yöntemidir (Yıldırım ve Şimşek, 2013). Bu doğrultuda, öncelikle araştırma soruları doğrultusunda çalışma grubunda yer alacak öğretmenlere ilişkin olarak "Ankara ili merkez ilçelerinde yer alan devlete bağlı mesleki ve teknik eğitim okullarında görev yapmak ve aynı zamanda Mesleki ve Teknik Eğitim Genel Müdürlügü̈’ne bağlı olarak 2012-2016 yılları arasında yapılan program geliştirme komisyonunda görev almak" ölçütü belirlenmiştir. Bu ölçütü karşllayan toplam 34 öğretmen arasından araştırmacının sahip olduğu kaynaklar ve imkânlar doğrultusunda, öğretmenlerin görev yaptıkları okulların yer aldığı merkez ilçeler, mesleki deneyim, cinsiyet, alan/dal dikkate alınarak 19 mesleki ve teknik eğitim öğretmeninin gönüllü katılımıyla çalışma grubu oluşturulmuştur. Bu öğretmenlere ait özellikler Tablo 1'de verilmiştir.

\section{Tablo 1. Çalışma Grubuna Ait Özellikler}

\begin{tabular}{|c|c|c|c|c|c|}
\hline \multicolumn{6}{|c|}{ Çalışma Grubunda Yer Alan Atölye, Laboratuvar ve Meslek Dersleri Öğretmenlerinin } \\
\hline Kodu & Cinsiyeti & $\begin{array}{l}\text { Yaş } \\
\text { Aralığ } 1\end{array}$ & $\begin{array}{c}\text { Mesleki } \\
\text { deneyimi }\end{array}$ & Eğitim durumu & $\begin{array}{l}\text { Alan/dalların ilişkili olduğu } \\
\text { sektör }\end{array}$ \\
\hline Ö1 & $\mathrm{E}$ & $25-35$ & $6-10$ & Lisans & Otomotiv \\
\hline Ö2 & $\mathrm{E}$ & $36-45$ & $16-20$ & Lisans & Bilişim Teknolojileri \\
\hline Ö3 & $\mathrm{E}$ & $25-35$ & $11-15$ & Lisans & Tekstil, Hazır Giyim, Deri \\
\hline Ö4 & $\mathrm{K}$ & $25-35$ & $1-5$ & Y. Lisans & $\begin{array}{l}\text { Toplumsal } \\
\text { Hizmetler }\end{array}$ \\
\hline Ö5 & $\mathrm{E}$ & $36-45$ & $16-20$ & Lisans & $\begin{array}{l}\text { Toplumsal ve Kişisel } \\
\text { Hizmetler }\end{array}$ \\
\hline Ö6 & $\mathrm{K}$ & $46-55$ & $21-25$ & Lisans & Ticaret (Satış ve Pazarlama) \\
\hline Ö7 & $\mathrm{K}$ & $36-45$ & $11-15$ & Lisans & Elektrik ve Elektronik \\
\hline Ö8 & $\mathrm{E}$ & $56-65$ & $16-20$ & Lisans & Tarım, Avcılık ve Balıkçılık \\
\hline Ö9 & $\mathrm{E}$ & $36-45$ & $16-20$ & Lisans & $\begin{array}{l}\text { Toplumsal ve Kişisel } \\
\text { Hizmetler }\end{array}$ \\
\hline Ö10 & $\mathrm{E}$ & $36-45$ & $11-15$ & Lisans & İnşaat \\
\hline Ö11 & $\mathrm{K}$ & $25-35$ & $1-5$ & Y. Lisans & Konaklama, Yiyecek-İçecek \\
\hline Ö12 & $\mathrm{E}$ & $36-45$ & $11-15$ & Lisans & İnşaat \\
\hline Ö13 & $\mathrm{E}$ & $46-55$ & $16-20$ & Lisans & Otomotiv \\
\hline Ö14 & K & $36-45$ & $16-20$ & Y. Lisans & $\begin{array}{l}\text { Kimya, Petrol, Lastik ve } \\
\text { Plastik }\end{array}$ \\
\hline Ö15 & $\mathrm{K}$ & $36-45$ & $16-20$ & Lisans & Konaklama, Yiyecek-İçecek \\
\hline Ö16 & $\mathrm{K}$ & $36-45$ & $16-20$ & Lisans & Tekstil, Hazır Giyim, Deri \\
\hline Ö17 & $\mathrm{E}$ & $36-45$ & $16-20$ & Y. Lisans & Medya, İletişim ve Yayıncılık \\
\hline Ö18 & $\mathrm{E}$ & $25-35$ & $1-5$ & Lisans & Cam, Çimento ve Toprak \\
\hline Ö19 & $\mathrm{K}$ & $46-55$ & $21-25$ & Lisans & Ticaret (Satış ve Pazarlama) \\
\hline
\end{tabular}




\section{Veri Toplama Aracı}

Araştırmanın temel veri toplama aracı, araştırmacılar tarafından geliştirilen yarı yapılandırılmış bireysel görüşme formudur. Yarı yapılandırılmış bireysel görüşme formunun geliştirilme sürecinde Yıldırım ve Şimşek (2013) tarafından önerilen ilkeler, araştırma problemleri doğrultusunda dikkate alınmıştır. Bu bağlamda, öncelikle araştırma problemleri doğrultusunda gerçekleştirilen alan yazın taraması kapsamında taslak görüşme formu oluşturulmuştur. Sonrasında bu taslak görüşme formu; Ankara, Dicle, Ege, Hacettepe ve Uludağ Üniversitesi'nde Eğitim Programları ve Öğretim anabilim dalında görev yapan 10 öğretim üyesi; Gazi Üniversitesi Ölçme ve Değerlendirme ana bilim dalında görev yapan bir öğretim üyesi ile Amasya Üniversitesi'nde görev yapan ve nitel araştırma konusunda deneyimli bir öğretim üyesinin görüşlerine sunulmuştur. Uzmanlardan gelen görüş ve öneriler doğrultusunda, bazı sorularda kullanılan kelimeler daha açık ve anlaşılır olması için değiştirilmiş veya bazı alt sorular/sondalar eklenmiştir. Bu aşamadan sonra çalışma grubunun özelliklerini taşıyan iki mesleki ve teknik eğitim öğretmeni ile pilot çalışmalar yapılmıştır. Bu kapsamda yapılan görüşmeler ile birlikte, görüşmelerin ne kadar süreceği, soruların anlaşılırllğg gibi durumlar test edilmiştir. Pilot çalışmadan sonra oluşturulan nihai görüşme formu toplam iki bölümden oluşmaktadır. İlk bölüm, öğretmenlerin demografik özelliklerine (cinsiyet, yaş, eğitim durumu vb.) ilişkin toplam 4 sorudan oluşan kişisel bilgiler bölümüdür. İkinci bölümde, öğretmenlerin eğitim programı kavramına ilişkin görüşlerinin ortaya konulması amacıyla hazırlanan üç temel soru ve bu sorulara iliş̧in olarak hazırlanmış sonda sorular yer almaktadır.

\section{Veri Toplama Süreci}

Araştırmanın veri toplama sürecine başlanmadan önce, Hacettepe Üniversitesi Etik Komisyonu'na başvuru yapılmıştır. Etik komisyon izni alındıktan sonra, araştırmanın odağ dâhilinde belirlenen özelliklere uygun öğretmenlere ulaşılması için Mesleki ve Teknik Eğitim Genel Müdürlügü̈ Programlar ve Öğretim Materyalleri Daire Başkanlığı'na başvurularak izin alınmıştır. Veri toplama süreci için gerekli tüm izinler tamamlandıktan sonra, çalışma grubu dâhilinde belirlenen öğretmenlere, telefon veya e-posta yoluyla ulaşılarak; araştırma ve bireysel görüşmelerle ilgili bilgiler verilmiştir. Araştırmaya gönüllü olarak katılmayı kabul eden öğretmenlerle, görüşme öncesinde iletişime geçilerek uygun oldukları gün ve saate göre görüşme takvimi oluşturulmuştur. $\mathrm{Bu}$ takvim çerçevesinde, tüm veriler yüz yüze görüşmelerle toplanmıştır. Ortalama 25-35 dakika süren görüşmeler katılımcı onayı alınarak ses kayıt cihazı ile kaydedilmiştir.

\section{Veri Analizi}

Veriler, içerik analizi ile çözümlenmiştir. İçerik analizinde, birbiri ile ilişkili verilerin belirli kavram ve temalarla bir araya getirilerek düzenli bir şekilde okuyucuya sunulması amaçlanmaktadır (Yıldırım ve Şimşek, 2013). Bu amaç doğrultusunda, metin veya metinlerden oluşan bir kümenin içindeki belli kelime ve kavramların varlığı ve birbirleri ile olan ilişkileri belirlenmeye çalış1lır (Büyüköztürk, Kılıç-Çakmak, Akgün, Karadeniz, Demirel; 2014). Bu bağlamda, içerik analizi süreci (1) ham verilerin elde edilmesi; (2) veri setinin analize hazırlanması; (3) verilerin kodlanması; (4) temaların oluşturulması; (5) kod ve temaların düzenlenmesi ve (6) bulguların tanımlanması ve yorumlanması (Creswell, 2014; Y1ldırım ve Şimşek, 2013) olmak üzere altı aşama kapsamında yürütülmüştür. Tablo 2'de eğitim programı tanımı kapsamında oluşturulan tema ve kod listesinden örnekler sunulmuştur. 
Tablo 2. Eğitim Programı Tanımı Kapsamında Oluşturulan Tema ve Kod Listesinden Örnekler

\begin{tabular}{|c|c|c|c|c|c|}
\hline Rehber & Resmî Belge & Gelişime Açık Belge & Çerçeve & İşlevsel Belge & Sistem \\
\hline $\begin{array}{l}\text { Kilavuz } \\
\text { Yol gösteren } \\
\text { Birincil } \\
\text { kaynak } \\
\text { Planlama } \\
\text { belgesi } \\
\text { Başvuru } \\
\text { kaynağ1 }\end{array}$ & $\begin{array}{c}\text { TTKB } \\
\text { Onaylı } \\
\text { doküman } \\
\text { Zorunluluk } \\
\text { Resmi } \\
\text { Devlet } \\
\text { Politika } \\
\text { belgesi } \\
\text { Bağlayıcılığı } \\
\text { olan }\end{array}$ & $\begin{array}{l}\text { Değişen } \\
\text { Gelişen } \\
\text { Yaşayan bir belge } \\
\text { Güncel gelişmeler } \\
\text { Bilimsel bilginin } \\
\text { devamlılığ } \\
\text { Farklılaşmalar }\end{array}$ & $\begin{array}{c}\text { Ortak } \\
\text { faaliyetler } \\
\text { Hedef ve } \\
\text { sinırlar } \\
\text { Eğitim } \\
\text { birlikteliği } \\
\text { sağlamak } \\
\text { Ana yol }\end{array}$ & $\begin{array}{c}\text { İhtiyaçlar } \\
\text { Geçerli bilgiler } \\
\text { İstihdam } \\
\text { Hayata } \\
\text { hazırlayan } \\
\text { Topluma uyum } \\
\text { Yetkinlik } \\
\text { kazandırma }\end{array}$ & $\begin{array}{c}\text { Girdi } \\
\text { Çıktı } \\
\text { Süreç } \\
\text { Ön koşullar } \\
\text { Birbiri ile } \\
\text { ilişkili bilgi } \\
\text { birimleri }\end{array}$ \\
\hline
\end{tabular}

\section{Bulgular}

Mesleki ve teknik eğitimde program geliştirme çalışmalarında görev alan atölye, laboratuvar ve meslek dersleri öğretmenlerinin eğitim programına ilişkin görüşlerinin incelenmesi amacıyla yarı yapılandırılmış bireysel görüşme formu aracılığıyla elde edilen ve içerik analizi ile çözümlenen bulgular, çalışmanın temel problemleri olan (a) eğitim programına ilişkin tanımlar (b) eğitim programının öğeleri (c) eğitim programının işlevleri çerçevesinde sunulmuştur.

\section{Mesleki ve Teknik Eğitim Öğretmenlerinin Eğitim Programına İlișkin Tanımları}

Araştırmanın birinci temel problemine ilişkin bulgular öğretmenlerin eğitim programını; "rehber", "resmi belge", "gelişime açık belge", "çerçeve", "işlevsel belge" ve "sistem" olmak üzere altı tema çerçevesinde tanımladıklarını göstermiştir. Araştırmaya katılan tüm öğretmenler eğitim programının, eğitim-öğretim faaliyetlerinde "rehber" olduğunu düşünmektedir. Eğitim programını, bu bağlamda tanımlayan bir öğretmen (Ö2) şunları ifade etmiştir:

Öğretmen ögrenmeye kllavuzluk ederken bir standarda, başka bir kilavuza ihtiyaç duyar. Sinıf ortamin düzenlemede, ön hazırlı yapmada, öğrencileri değerlendirmede bile ĕgitim programına ihtiyaç duyar. Kazanımları, konuları, ders saatlerini, derslerin senelerini programdan görür. Bu açıdan program ögretmen için vazgeçilmez bir kılavuzudur.

Diğer bir öğretmen (Ö8), birçok farklı unsurdan oluşan bir yapıya sahip olan mesleki ve teknik eğitimde eğitim programının, öğretmenler için önemli bir rehber olduğunu vurgulayarak şunları ifade etmiştir:

...mesleğin tanıml, yeterlilikleri, görevleri, alanda kullanılan teknoloji, meslekte uyulması gereken kurallar... Öğretmenin gerçekten o eğitimi planlı bir şekilde verebilmesi için böyle birçok şeyin elinin altında olması lazım. Bundan dolayı eğitim programı bütün eğitimin en başından en sonuna kadar önemli bir rehberdir diyebilirim.

Bir diğer öğretmene (Ö14) göre eğitim program1, öğretmenin eğitim-öğretim faaliyetlerinde ihtiyaç duyduğu tüm bilgileri barındıran bir kaynak olarak öğretmene yol göstericidir: "Program öğretmenin $5 \mathrm{~N} 1 \mathrm{~K}$ sorularının cevabını bulabildiği, eğitimi nasıl başlatacak? Nasıl sürdürecek? Nasıl sonlandıracak? Bunlarla alakalı tüm soruların cevaplarının olduğu bir kaynak k1lavuzdur." 
Araştırmaya katılan altı mesleki ve teknik eğitim öğretmeninin eğitim programına ilişkin ortaya koydukları tanımlarda eğitim programının resmi bir niteliğe sahip olduğu vurgulanmıştır. "Resmi belge" olarak eğitim programı tanımlarında programın; bir ülkenin eğitim hedefleri ve eğitim politikası doğrultusunda hazırlanması, bir devlet kurumu olarak resmi nitelik taşıyan Milli Eğitim Bakanlığı'nın (MEB) ilgili birimi Talim ve Terbiye Kurulu Başkanlığı (TTKB) tarafından onaylanarak uygulamaya konulması ifadelerine yer verilmiştir. Eğitim programının resmi belge niteliğine vurgu yapan öğretmenlerden Ö1 eğitim programını “... bir ülkenin politikaları ve eğitim sisteminin hedefleri doğrultusunda; öğrencilerde sahip olunmasını istediğimiz kazanımların ve bu kazanımlara ulaşmak için faydalandığımız, kullandığımız tüm bilgilerin yer aldığı, TTKB tarafından onaylı doküman." olarak tanımlamıştır. Eğitim programının resmi bir belge olma özelliğini ön plana çıkaran diğer bir öğretmenin (Ö10) görüşleri ise şöyledir: "Eğitimin yapılandırılması ve eğitim süreçlerinin amaçlar doğrultusunda planlanmasını sağlayan, ülkenin üst düzey politika belgeleri arasındadır."

Araştırmaya katılan mesleki ve teknik eğitim öğretmenlerinin eğitim programı tanımlarına ilişkin olarak yürütülen içerik analizinden elde edilen diğer bir tema "gelişime açık belge" olarak eğitim programıdır. Bu tema çerçevesinde görüş bildiren beş öğretmen, eğitim programının birçok faktörün etkisiyle sürekli devam eden dinamik bir gelişim sürecinde ilerleyen bir doküman olduğunu vurgulamışlardır. Örneğin bir öğretmen (Ö4) tarafından eğitim programı “...gelişen bir olgudur. Ülkenin eğitim felsefesinde, toplumsal dinamiklerde, bilimsel doğrularda meydana gelen her türlü değişimlerin ve teknolojik gelişmelerin etkisiyle değişir ve de gelişir." ifadeleri ile tanımlamıştır. Ö9 ise, eğitim programlarının sürekli bir gelişim içinde olmasını mesleki ve teknik eğitimde uygulanmakta olan eğitim programı ile ilişkilendirerek şunları ifade etmiştir:

...Özellikle mesleki eğitimde, eğitim verilecek alan ve dalda olan bu yetkinlikler güncel gelişmelerin, teknolojik gelişmelerin etkisiyle değiştiğinde eğitim programına anında yansır. Genel eğitimde de derslerin içerikleri bilimin ilerlemesiyle gelişir. Eğitim programları da dünyada ne kadar farklılaşma varsa, bilimde, doğada, uzayda, toplumlarda... Bu farklllaşmalarla farklllaşan bir programdır.

Araştırmaya katılan mesleki ve teknik eğitim öğretmenlerinin eğitim programı tanımlarına ilişkin yapılan içerik analizinden elde edilen diğer bir tema olan "çerçeve doküman" olarak eğitim programı, üç öğretmen tarafından vurgulanmıştır. Eğitim programını çerçeve doküman olarak tanımlayan öğretmenler, programın ülke genelinde yürütülen eğitim-öğretim faaliyetlerinde belirli düzeyde ortaklık ve esneklik sağlaması yönünde birleşmektedir. Eğitim programının bu yönüne ağırlık vererek tanımlayan bir öğretmen (Ö1) “...bu doküman (eğitim programı) eğitim sisteminin ortak faaliyetlere ve ortak bir çabaya dayalı olması için uyulması gereken ortak bir yapı olarak da ülke genelindeki eğitimle ilgili bütün faaliyetlerin benzer olmasını sağlıyor" şeklinde görüş bildirerek eğitim programının, ülke genelindeki eğitimöğretim faaliyetlerinde ortak koşul ve imkânların sağlanmasına ilişkin bir çerçeve oluşturduğunu vurgulamıştır. Benzer şekilde, Ö11'de eğitim programını “....ayrıntılarını öğretmenlerin tamamladığı genel çerçeve özelliği taşır. Alana ait görevlerin, yeterliliklerin ve işlemlerin olduğu sınırları çizen genel olarak bir çerçeve özelliği var." şeklinde tanımlayarak, sınırları ortaya koyan çerçeve niteliğinde doküman olarak ele almıştır. 
Eğitim programı tanımına ilişkin bir diğer tema olan "işlevsel belge" olarak eğitim programı üç öğretmen tarafından ifade edilmiştir. Bu öğretmenlere göre eğitim programı, bireylerin ve toplumun ihtiyaçlarının karşılanmasına imkân veren işlevsel bilgilerin yer aldığ dokümanlardır. Eğitim programının işlevsel bir belge olması, Ö6 tarafından öğrencilerin hayata hazırlanması ile ilişkilendirilerek şöyle açıklanmıştır: "Öğrenciler için de eğitim programı en az öğretmenler kadar önemlidir çünkü eğitim programında bu şekliyle öğrencinin hayatta kullanması gereken bütün bilgiler bir düzen içinde planlanır. Öğrenci odaklı düşündüğümüzde öğrencileri hayata hazırlar diyebiliriz." Diğer bir öğretmen Ö18 ise eğitim programı ile eğitimin işlevsel bir yapı kazandığına dikkat çekerek şunları belirtmiştir: “...tüm insanları eğitim için; işe yaramayan, geçerliliği ve doğruluğu olmayan verilerin olduğu imkânsız ve faydasız bir uğraştan alıkoyan bir belgedir."

Araştırmaya katılan öğretmenlerin eğitim programı tanımlarından elde edilen bulgulardan ortaya çıkan diğer bir tema "sistem" olarak eğitim programıdır. Belli parçaların ve süreçlerin bir araya gelerek oluşturduğu bir sistem olarak ele alınan eğitim programı kavramı iki öğretmen tarafından vurgulanmıştır. Bu öğretmenlerden Ö15'e ait görüşler şu şekilde ifade edilmiştir:

Eğitim programı, hedef kazanımların belli ön koşullara ya da seviyelendirmeye
uygun şekilde planlanmasından sonra bu hedef kazanımların gerçekleştirilmesi için
bunlara uygun bir şekilde ders, konu gibi anlamlı bütünleri oluşturan içeriklerin
eğitim-öğretim sürecinde uygulanmasın son olarak bu sürecin sonundaki çıtıtının
değerlendirme kriterlerini gösteren materyaldir.

Mesleki ve Teknik Eğitim Öğretmenlerinin Eğitim Programının Öğelerine Yönelik Görüşleri

Araştırmanın "Mesleki ve teknik eğitimde program geliştirme çalışmalarında görev alan atölye, laboratuvar ve meslek dersleri öğretmenlerinin eğitim programının öğelerine yönelik görüşleri nelerdir?" olarak belirlenen ikinci problemine ilişkin bulgularda, öğretmen görüşleri Şekil 1'de verildiği gibi; hedefler, içerik, eğitim durumları, sınama durumları ve kapsayıcı açıklamalar öğelerine odaklanmaktadır.

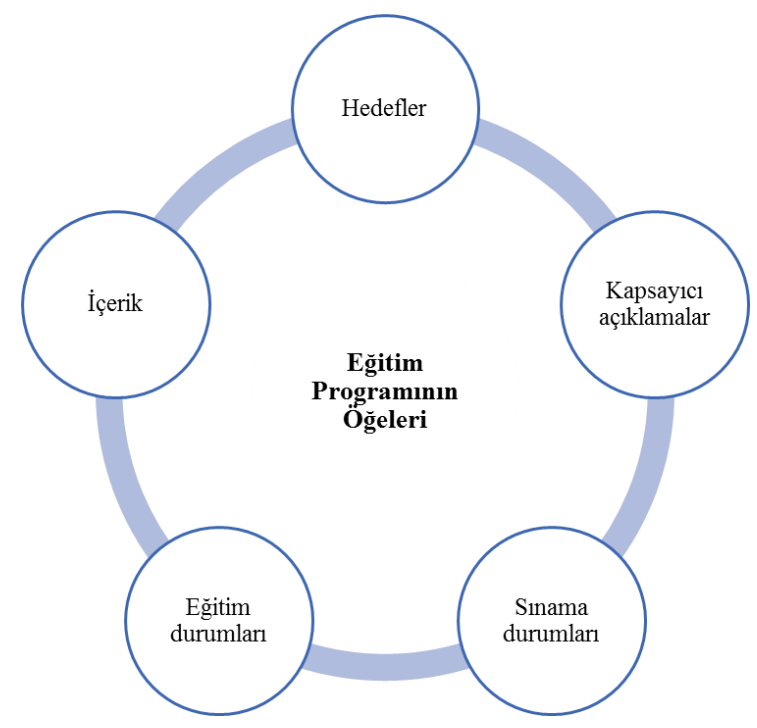

Şekil 1. Öğretmenlerin eğitim programının öğelerine ilişsin görüşleri 
Araştırmaya katılan öğretmenlerin 16'sı tarafından “içerik" öğesi, eğitim programında bulunması gereken temel öğelerden biri olarak ifade edilmiştir. İçerik öğesi bazı öğretmenler tarafından "konu" bazıları tarafından da "ders" ifadeleri kullanılarak açıklanmıştır. İçerik öğesine ilişkin bir öğretmene (Ö6) ait görüşler şöyledir: "Dersler olmalı tabi ki. Derslerle ilgili her şey olmalı. Süresi, amacı olmalı, konular olmalı." Eğitim programında içerik öğesini konular kapsamında ifade eden bir öğretmen (Ö7) ise içeriğin gerekliliğini şöyle açıklamıştır: “... konular kesinlikle olmalı, programlar da buna göre düzenlenmeli. Öğrencilere kazandırılacak bütün yeterlilikleri ilgilendiren bir konu alanı var çünkü.” Bir diğer öğretmen (Ö11) de, içerik öğesinin güncel ve ihtiyaca cevap veren yapısına dikkat çekerek şunları ifade etmiştir: "Sektörün ihtiyaçlarına ve teknolojik gelişmelere göre güncel bir şekilde düzenlenmiş konular olmalı. Konular olmazsa istenilen hedeflere ve kazanımlara öğrencileri ulaştıramayız." Bir diğer öğretmen (Ö5) ise, "hedeflere yön veren içerik" ifadesiyle, hedeflerin içerik öğesi temelinde şekillendiğini vurgulamıştır.

Araştırmaya katılan öğretmenlerin eğitim programının öğelerine ilişkin ortaya koydukları görüşlerin analizinden elde edilen bulgularda, "hedefler" programın temel öğelerinden biri olarak 14 öğretmen tarafından belirtilmiştir. Hedef öğesi bazı öğretmenler tarafından "amaç" bazıları tarafından da "kazanım" ifadeleri ile açıklanmıştır. Bir öğretmen (Ö8) "Eğitim programında en önemlisi amaçlar yani hedefler olmalı. Bu amaçlar ve hedefler ana unsur, en önde giden unsur" şeklindeki ifadesinde, eğitim programının temel öğesi olarak hedefleri ele almaktadır. Benzer şekilde eğitim programının bir amaç doğrultusunda hazırlanması gerektiğini düşünen Ö14 ise "Eğitim programının amacı olmalıdır. Amaç olmadan sonuca ulaşmak mümkün değildir. Niçin sorusuna cevap vermelidir. Eğitim programı niçin hazırlanmıştır?" ifadeleri ile açıklamıştır. Diğer bir öğretmen Ö2 ise kazanımları eğitim programının en önemli öğesi olarak nitelendirirken, diğer öğelerin kazanımlara ulaşmak için birer araç görevi üstlendiğini şöyle açıklamıştır: "En önemli öğemiz tabi ki kazanımlar. Diğer öğelerin tamamı kazanımlara ulaşmak için gerekli araçlardır."

Eğitim programının öğelerine yönelik öğretmen görüşleri incelendiğinde, 11 öğretmenin "sınama durumları" öğesine ilişkin görüş bildirdiği görülmektedir. Öğretmenlere göre sınama durumlarının eğitim programının vazgeçilmez öğelerinden biri olmasının altında yatan temel sebep, öğrenci ve programla ilgili dönütlerin bu öğe aracilığıyla elde edilmesidir. Bir öğretmen (Ö4) bu durumu "Değerlendirme kısmı mutlaka olmalıdır bu kısımda hedeflere ulaşılıp ulaşılmadığı, eksiklikler ve kazanımların düzeyleri belirlenmelidir. Eğitim programında bence en önemli öğe değerlendirme kısmıdır. Programda yanlışlar ve değiştirilecek kısımlar burada ortaya çıkar." ifadeleriyle açıklamıştır. Eğitim programında ölçme ve değerlendirmenin gerekliliğini vurgulayan bir diğer öğretmen ise (Ö3) “...kazanımlara ne kadar ulaşılmış ne kadar ulaşılmamış bunları ise ölçme ve değerlendirme ile anlayabiliriz.” olarak görüşlerini ifade etmiştir.

Araştırmaya katılan öğretmenlerin eğitim programının öğelerine ilişkin görüşleri incelendiğinde, eğitim programının temel öğelerinden biri olarak "eğitim durumları" öğesi sekiz öğretmen tarafından ifade edilmiştir. Bu öğretmenlerin eğitim durumlarını, dersin işlenişinde kullanılacak strateji, yöntem, teknik, araç-gereçler kapsamında ele aldıkları görülmektedir. Öğretmen Ö9 eğitim ortamı ve araç-gereçler bağlamında ele aldığı eğitim durumları öğesini şöyle açıklamıştır: "Eğitim programında kullanılacak araç-gereçlerin iyi tespit edilmesi 
gereklidir bu eğitim programı hangi araç gereçlerle öğrenciye yansıtılacaksa eğer onun dışında ortamın iyi belirlenmiş olması gerekir eğitim programının içinde.” Benzer şekilde, eğitim durumları öğesi kapsamında yöntem ve teknik, araç-gereç gibi unsurlara değinen bir diğer öğretmen (Ö19) ise şunları ifade etmiştir: "Sınıf içinde yapılan tüm etkinlikler, öğretmenin kullanacağ1 yöntem ve teknikler, ders esnasında kullanacağı tüm araç ve gereçler, her bir öğrenciye istenen hedeflerin ne kadar sürede kazandırılacağı gibi konular netleştirilmelidir."

Araştırmaya katılan yedi öğretmen tarafından, eğitim programı kapsamında yer alması gereken öğe "kapsayıcı açıklamalar" olarak ifade edilmiştir. Kapsayıcı açıklamalara ilişkin olarak belirtilen görüşlerin ortak noktası, programın özellikle uygulama aşamasına 1şık tutacak örnekler, uyarılar, bilgi metinleri gibi açıklamaların gerekliliğinin ifade edilmesidir. Eğitim programında özellikle öğretmenler için kapsayıcı açıklamalara mutlaka yer verilmesi gerektiği Ö4 tarafindan şöyle ifade edilmiştir:

\begin{abstract}
Bir eğitim programinda ögretmen ve ögrenciye yönelik açılklamalar olmall. Ama öncelikle tabii ki ögretmene yönelik. Uygulama ile ilgili, yöntem ve teknik ile ilgili içerikle ilgili ve ölçme ile ilgili kusaca programda olması gereken her şeyin açıklaması öğretmene yol göstermek için olmalı. Meslekle ilgili açıklama olmalı. Bu genel alanın amacı ya da alan kazanımı olmall.
\end{abstract}

Ö12 ise, eğitim programında okul yöneticilerine ve müfettişlere yönelik kapsayıcı açıklamaların da bulunması gerektiğini şöyle açıklamıştır:

...hem okul idarecilerine, ögretmenleri denetleyen müfettişlere, denetmenlere yönelik açıklamalar olabilir. Ayrıca öğretmenlere yönelik açılamalar olabilir. Çünkü öğretmen programı uygulayacak ögrencilere hedeflenen davranışlar kazandırılacak, programın sağlıklı uygulanıp/uygulanmadı̆̆ını da idareciler kontrol edecek. Dolayıslyla her iki ögrretmenin uygulamast yöneticilerin/idarecilerin değerlendirilmesini ne derece nasıl sağlıklı yapılacă̆ı konusunda bence açılamalara yer verilmeli.

\title{
Mesleki ve Teknik Eğitim Öğretmenlerinin Eğitim Programının İşlevlerine İlişkin Görüşleri
}

Araştırmanın "Mesleki ve teknik eğitimde program geliştirme çalışmalarında görev alan atölye, laboratuvar ve meslek dersleri öğretmenlerinin eğitim programının işlevlerine yönelik görüşleri nelerdir? olarak belirlenen son problemi doğrultusunda gerçekleştirilen içerik analizinden elde edilen bulgular Şekil 2'de verildiği gibi; "öğretmen açısından işlevleri”, "öğrenci açısından" işlevleri”, "toplum açısından işlevleri”, "konu alanı açısından işlevleri”" olmak üzere dört tema çerçevesinde incelenmiştir.

Araştırmaya katılan öğretmenlerin eğitim programının öğretmene yönelik işlevlerine ilişkin ifade ettikleri görüşlerden elde edilen bulgularda, "öğretime rehberlik", "mesleki gelişimde süreklilik", "mesleki yükümlülükte adil dağılım”, "meslekte yasal dayanak" olmak üzere dört temel işlev ortaya konulmuştur. Araştırmaya katılan öğretmenler, eğitim programının öğretmen açısından öncelikli olarak; öğretim sürecinin planlaması, uygulanması ve değerlendirilmesinde bir rehber işlevine sahip olduğu konusunda hemfikirdir. "Öğretime rehberlik" teması kapsamında bir öğretmen (Ö16) görüşlerini şöyle ifade etmiştir: “...(öğretmenin) öğrencinin seviyesine uygun ders işlemesini, yine seviyeye ve hedef kazanıma uygun konu başlıkları, öğrenci materyalleri, ders kitapları, sınıf ortamı hazırlayabilmesini 
sağlar”. Diğer bir öğretmen Ö6 eğitim programının; planlama, uygulama ve değerlendirme süreçleri kapsamında gerçekleştirilen tüm faaliyetlerde öğretmene rehberlik etmesinin yanında; emek, zaman, kaynak kullanımı vb. konularda da yönlendirici olduğunu vurgulayarak şunları söylemiştir: "Öğretmene yön verir. Zamanı, kaynakları ve enerjisini verimli kullanmasında rehberdir. Programda yer alan her parçayı öğretmene organize ederek sunar. Öğretmen yıllık planını programa göre hazırlar, programa göre yöntemini tekniğini ya da sınavını seçer”.

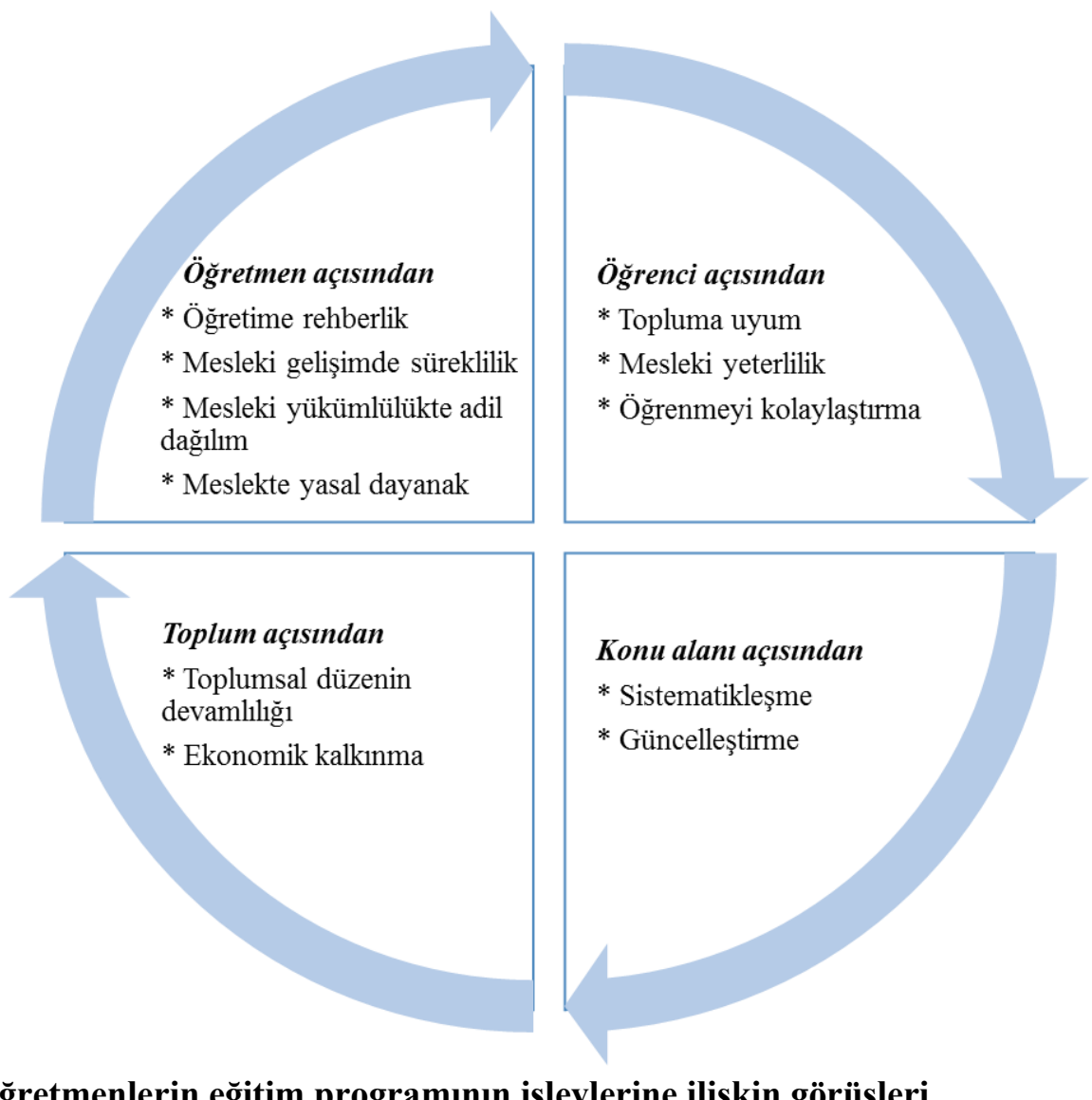

\section{Şekil 2. Öğretmenlerin eğitim programının işlevlerine ilişkin görüşleri}

Eğitim programının öğretmene yönelik işlevleri kapsamında vurgulanan diğer bir tema "mesleki gelişimde süreklilik" işlevidir. Bu işlevi vurgulayan üç öğretmen, değişen ihtiyaçlara uygun olarak yenilenen eğitim programları ile birlikte öğretmenlerin de söz konusu yeniliklere paralel olarak mesleki becerilerini güncellemeleri ve geliştirmeleri gerektiği konusunda hemfikirdir. Bu işleve odaklanan öğretmenlerden biri olan Ö4 görüşlerini şöyle açıklamıştır: "Öğretmenin kendini yenilemesini ve geliştirmesini sağlar. Programda yer verilecek yeni içeriği gören öğretmen buna uymak için kendini de geliştirir bu şekilde mesleki gelişimine de katk1 sağlar." Benzer noktalara vurgu yapan Ö3 şunları ifade etmiştir: “...Programda her yeni kazanım sadece öğrencinin kazanımı olmuyor öğretmenin de kazanımı oluyor çünkü o kazanımın gerçekleşmesi için öncelikle öğretmen bilmeli ya da yapabilmeli, bilişsel mi psikomotor mu? Ona göre. Bu açıdan baktığımızda eğitim programı öğretmenlere de bilgi, beceri kazandırır."

Öğretmen açısından eğitim programının işlevleri kapsamında iki öğretmen tarafindan ön plana çıkarılan bir diğer işlev "mesleki yükümlülükte adil dağılım” işlevidir. Bu işlevi 
vurgulayan öğretmenlere göre eğitim programı, tüm eğitim-öğretim faaliyetlerini ortak bir zemine oturtmakta ve bununla birlikte öğretmenlerin ortak veya benzer mesleki sorumluluklar üstlenmelerini ve dolayısıyla öğretim sürecinde mesleki eşitliği sağlamaktadır. Bu işleve yönelik Ö19'un görüşleri şöyledir: “... sürecin herkes için aynı şekilde ilerlemesini sağlar. Program olmasa mesela bir öğretmen bir görevde altı yeterlilik sıralayıp ders içeriğini oluşturur; diğeri sekiz yeterlilikle dersi oluşturur. Öğretmen ya gereğinden çok gayret sarf edecek ya da ögrencileri eksik bilgilerle mezun edecek."

Eğitim programının öğretmen açısından "meslekte yasal dayanak" işlevi araştırmaya katılan iki öğretmen tarafindan ortaya konulmuştur. Bu işlev kapsamında, eğitim-öğretim faaliyetinin öğretmenler tarafindan resmi bir program dâhilinde öngörülebilir bir süreç çerçevesinde yürütülmesinin önemine dikkat çeken Ö18 görüşünü şu şekilde açıklamıştır: "Onaylanmış, üstünde komisyon tarafindan çalışılmış, girdileri çıktıları görülmüş, sürece de aynı şekilde yer verilmiş bir eğitim programı tüm belirsizliklerin cevabı olacağı için öğretmene güven verir. Öğretmen öğrencileri nereden alıp nereye bırakacağını görür." Bir diğer öğretmenin (Ö13) bu işleve yönelik görüşleri ise şöyledir: “... Öğretmenin bir görev tanımı gibidir. Okul içinde ne yapması gerektiğini gösterir. Öğretmenin kazandıracağı kazanımların, bunun için gerekli içeriklerin programda olması öğretmenin yasal bir dayanağı olur. Hiçbir makam merci sen neden bunu öğrencilere öğrettin, neden bu konuyu işledin diyemez."

Araştırmaya katılan öğretmenlerin eğitim programının öğrencilere yönelik işlevlerine ilişkin ortaya koydukları görüşlerden elde edilen bulgularda; "öğrenmeyi kolaylaştırma”, "mesleki yeterlilikler”, "topluma uyum”, olmak üzere üç temel işlev ortaya konmuştur. Eğitim programının öğrenci açısından işlevlerinden ilki olan "mesleki yeterlilikler" 10 öğretmen tarafından ifade edilmiştir. Bu işlevin vurgulandığı öğretmen görüşlerinin ortak noktası; eğitim programının öğrencilere, bir mesleğe ait bilgi ve becerileri kazandırması, kariyer planlamasına destek olması, iş disiplini kazandırmasıyla ilişkilidir. Bu işleve önem veren öğretmenlerden biri olan Ö12 "Eğitim programları öğrencilere alanlarıyla ilgili bilgi becerileri kazandırır. Bu açıdan bakıldığında eğitim programları öğrencinin, sektöründe istihdamda bulunulmasına yardımcı olur." olarak ifade ettiği görüşünde eğitim programının mesleki yeterliliğe katkısının sonucu olarak istihdam edilebilirliğe değinmektedir. Eğitim programının öğrencilere mesleğin gerektirdiği bilgi, beceri ve tutumları kazandırarak mesleki yeterlilik kazandırma işlevi gördüğüne değinen diğer bir öğretmen ise (Ö17) şunları ifade etmiştir: "Meslekte ilerlemeyi sağlar. Meslek dalındaki bilgi, beceri ve tavırları kazandırır. ...meslekteki yeterliliklerle mezun olmasını sağlar."

“Öğrenmeyi kolaylaştırma” işlevine yönelik olarak yedi öğretmene ait görüşlere göre eğitim programı, öğrenci seviyesine ve ihtiyacına uygun; kazanım, içerik, eğitim-öğretim süreçleri olmak üzere öğrencilerin öğrenme sürecine olumlu etki yapan unsurları barındırmaktadır. Öğrenmeyi kolaylaştırma işlevine yönelik olarak görüş bildiren bir öğretmen (Ö8) görüşlerini şöyle ifade etmiştir: "Programda bir birimden diğerine doğru büyüyen bir sıralama var, önceki öğrenmelerin de üstüne kurulu bir sistem program. Bunlar bir de alan uzmanlarının bilgisiyle, bilimsel bir sürece de uygun şekilde programda çalışıldığında, öğrenci için kazanımlar ulaşılabilir oluyor." Öğretmen Ö18 ise, "Öncelikle yeterli bilgiye erişim sağlamasında işlevi vardır. Ne çok ne az yani. Sonra öğrenmenin daha kalıcı olmasını sağlar. Çünkü öğrenme aktiviteleri programlıdır. Bir sistematiği vardır. Kolaydan zora genelden özele 
yakından uzağa gibi... Bunlar da bilgilerin kalıcı olmasını sağlar." olarak ifade ettiği görüşlerinde eğitim programının öğrencinin ihtiyaç duyduğu düzey ve nitelikte bilgilere yer verilmesi ve bu bilgilerin öğretim ilkelerine uygun bir şekilde organize edilerek öğrenme sürecine aktarılmasının önemini vurgulamıştır.

Eğitim programının öğrenci açısından işlevlerine yönelik elde edilen bulgularda ortaya çıkan son işlev beş öğretmen tarafından vurgulanan "topluma uyum" işlevidir. Bu işleve ilişkin görüş bildiren öğretmenlerin vurguladıkları ortak nokta; toplumsal normların, milli ve manevi değerlerin kazandırılmasına ilişkin hedeflerle eğitim programının, öğrencilerin topluma uyum sağlama sürecinde kolaylaştırıcı bir işleve sahip olduğu yönündedir. Bu öğretmenlerden biri olan Ö9'a göre eğitim programı "Öğrencilerin Milli Eğitimin ve ülkenin ortak temel değerlerine sahip bireyler olarak yetişmesini sağlar. Böylece tüm sosyal çevresiyle çatışmalara girmeden uyumlu bir şekilde yaşamasını da sağlar." Diğer bir öğretmen (Ö5) bu işleve ait görüşlerini şöyle ifade etmiştir:

\section{Benzer niteliklerle mezun olan ögrrenci demek ayn zamanda vatandaş profilinin de bazı açılardan örtüşmesi demek. Burada eğitim almış bir Türk vatandaşının Türk kültürüne olan oryantasyonu ile Avrupa'da eğitim almış bir Türk vatandaşının oryantasyonu arasında ciddi bir uçurum ortaya çıkar. Baktığımızda ikisi de Türk vatandaşı aslında. Öğrenciler programla birlikte bu kültür aktarımı ile değerler ĕgitimi ile içinde bulunduğu, ferdi olduğu devlet ve milletle bütünleşebilir.}

Araştırmaya katılan öğretmenlerin eğitim programının topluma yönelik işlevlerine ilişkin ortaya koydukları görüşlerden elde edilen bulgularda, "toplumsal düzenin devamlılığı" ve "ekonomik kalkınma" olmak üzere iki temel işlev ortaya konmuştur. Bu işlevlerden ilki olan "toplumsal düzenin devamlılığı" teması altında 13 öğretmen tarafından eğitim programının; toplumsal normlar ve ihtiyaçlar, milli ve manevi değerler gibi toplumsal birikimler çerçevesinde hazırlanması sonucunda toplumsal düzenin devamlılığının sağlamasına vurgu yapılmıştır. Bu işlev Ö3 tarafından şöyle açıklanmıştır: "Toplumun ve uluslararası ortak değerlerin kazanılmasını sağlayarak bireyin hem topluma hem de dünyaya faydalı bir kişilik geliştirmesine katk1 sağlar. Değerler ve ortak bilinç etrafında öğrencilerin vatandaş olarak topluma katılmasını sağlar.” Benzer şekilde, başka bir öğretmen (Ö19) toplumsal sorun ve yeni ihtiyaçların eğitim programı aracılığıyla giderilmesini vurgulayarak şunları ifade etmiştir: "Eğitim programı; toplumun güncel sorunlarına, ihtiyaçlarına, hedeflerine cevap verir. Toplumsal problemler eğitimle aşılmaya çalışılır. Toplumla ilgili gelecek nesillere aktarılması gereken bir olay meydana geldiyse bunu toplu bir şekilde en iyi eğitim ile sağlayabiliriz."

Eğitim programının topluma yönelik işlevleri kapsamında sekiz öğretmen tarafindan vurgulanan "ekonomik kalkınma" işlevi, eğitim programı aracıllı̆ıyla yetişen nitelikli meslek elemanlarının iş piyasasını güçlendirmesi sonucunda ülkenin ekonomik kalkınmasını hızlandırması ile açıklanmaktadır. Bu kapsamda eğitim programının, ekonomik kalkınma işlevi Ö2 tarafindan şöyle açıklanmıştır: "Mesleki eğitimde ... sektörün ihtiyaçlarına önem verilir. Güncel ihtiyaçlara uygun hazırlanmış programlar kalifiye eleman ihtiyacını karşılayacaktır; bu durum sonuçta üretimi ve sanayileşmeyi olumlu etkiler. Ürettiğimiz mallarda kaliteyi yakalamamızı sağlar böylece ihracatımız da genişler. Çok fazla aslında bunun etki ağı."

Araştırmaya katılan öğretmenlerin eğitim programının konu alanı açısından işlevlerine ilişkin görüşlerinden elde edilen bulgularda, "güncelleştirme" ve "sistematikleştirme" olmak 
üzere iki temel işlev ortaya konmuştur. Bu işlevlerden ilki olan "güncelleştirme" 14 öğretmen tarafindan konu alanının teknolojik gelişmelere ve güncel ihtiyaçlara paralel olarak yenilenmesi ile birlikte güncelliğinin korunması odağında açıklanmıştır. Bu işleve ilişkin Ö9'un, görüşleri şöyledir: "Programın sürekli güncel tutularak yeniliklerden geri kalmaması gerekir. Özellikle bizim alanımızda sürekli değişen mevzuatın programa yansıtılması değişikliklerin hemen program içerisine aktarılması önemlidir. Konu alanı dediğimizde de programla birlikte güncellenir sürekli. Eklenenler olur çıkanlar olur". Bir diğer öğretmen ise (Ö16), eğitim programının ihtiyaç analizi sonucunda geliştirilmesi ile konu alanının güncelliğinin sağlandığını şöyle açıklamıştır:

Konu alanı açısından eğitim programinın olması sektörün nabzını tutuyorsun. Sektörün istediği doğrultuda ögrrenci yetiştirilmesine neden oluyor. Onlartn ihtiyaçları. Alan açısından da zaten programlar belirlenirken sektörün ihtiyaçları doğrultusunda belirlendiği için, sektörden talep ettikleri istihdam edecekleri ihtiyaç ne doğrultudaysa o doğrultuda programlar hazırlaniyor bu programlar da bütün alanların son gelişmeleri yakalamasını sağllyor.

Eğitim programının konu alanına yönelik işlevleri kapsamında dokuz öğretmen tarafından vurgulanan "sistematikleştirme" işlevi, konu alanına ait birbiri ile ilişkili işlem, yeterlilik, görev gibi program birimleri olarak tanımlanan öğelerin bir bütünü oluşturan parçalar olarak sistematik bir şekilde sınıflanması ve sıralanması ile ilişkilidir. Bu bileşenler için gerekli olan; süre, araç-gereç, eğitim materyali gibi unsurların planlı bir şekilde eğitim-öğretim süreçlerinde yer alması da öğretmenler tarafından eğitim programının konu alanı açısından işlevi olarak görülmektedir. Bir öğretmen (Ö2) tarafından eğitim programının bu işlevi şöyle açıklamıştır: "Konuları yutulabilir lokmalara parçalar, her parça için ayrı ayrı program öğeleri belirler. İşlem, yeterlilik... Bu yutulabilir parçalar için süre öğesi ayrı ayrı yazılır. Bunlar program işlevi, konu açısından işlev denilebilir.” Eğitim programının konu alanına yönelik "sistematikleştirme" işlevine ilişkin olarak diğer bir öğretmen (Ö11) ise kazanımlar, araç-gereç, eğitim ortamı gibi birçok farklı unsurun bilimsel araştırmalara uygun bir şekilde gerçekçi veriler ile programa yerleştirildiğini ifade etmiştir:

... eğitim programin elimize aldığımızda gelişi güzel olmayan bir bilimsel araştırması olan, bir uzmanın hatta birkaç uzmanın birlikte çalıştığı konular var. Parçalara ayrılmış, ilişkilendirilmiş, gerekli atölye, araç-gereç belirtilmiş. Hatta o konuyu ögretirken hangi değeri de ögretmemiz lazım gibi değerler eğitimi, tavirlar da belirlenmişs... Eğitim programı alan için bu yüzden çok önemli aslında.

\section{Tartışma ve Sonuç}

Mesleki ve teknik eğitimde program geliştirme çalışmalarında görev alan atölye, laboratuvar ve meslek dersleri öğretmenlerinin eğitim programına ilişkin görüşlerinin incelenmesi amacıyla yürütülen bu çalışmada, öğretmenlerin eğitim programını alan yazında kabul gören tanımlar ve öğeler paralelinde anlamlandırdıkları, eğitim programının işlevlerine ilişkin farkındalığa ve bilgi birikimine sahip oldukları sonucuna ulaşılmıştır.

Araştırmaya katılan öğretmenlerin eğitim programı kavramına ilişkin ortaya koydukları tanımlar incelendiğinde, öğretmenlerin tamamı programı, eğitim-öğretim faaliyetlerini düzenlemede bir rehber olarak nitelendirmektedir. Bununla birlikte eğitim programının kuramsal düzeyde ve uygulamada önem arz eden dinamik bir belge olması, işlevsel bilgilerin 
yer aldığı bir doküman olması, eğitim-öğretimin sınırlarını çizmesi ve aynı zamanda resmi niteliğe sahip olması gibi özelliklerin öğretmenler tarafından ifade edilmesi eğitim programı kavramı ile ilgili farkındalığa sahip olduklarını göstermektedir. Bunlara ek olarak, öğretmenlerin program tanımlarının geleneksel eğitim felsefeleri kadar çağdaş eğitim felsefelerine de vurgu yaptıkları söylenebilir. Örneğin öğretmen görüşleri sonucunda ortaya çıkan resmi program vurgusu, Varış (1978) tarafından; eğitim programının, milli eğitimin hedeflerinin gerçekleşmesine dönük faaliyetleri kapsamasına yönelik ifadeleri ile benzerlik göstermektedir. Ayrıca öğretmenlerin bu yaklaşımı, eğitim programının aynı zamanda politik bir belge olarak ele alınmasını savunan yeniden kavramsallaştırmacı program anlayışı ile benzerlik gösterdiği ve post-modern bir bakış açısından izler taşıdığı sonucuna ulaşılabilir. Yeniden kavramsallaştırmacılara göre günümüzde politikacılar, veliler ve sosyo-ekonomik güçler (yoğun göç veya ekonomik kriz vb.) okullar üzerinde daha güçlü bir etkiye sahiptir; bu nedenle eğitim programının sosyo-politik yanı göz ardı edilmemelidir (Bümen ve Aktan, 2014). Benzer şekilde öğretmenler tarafından yapılan eğitim programı tanımlarında, programın özellikle öğrenciler için işlevsel bir yapıda olması ile ilgili ifadelerin alan yazınla paralel olduğu İşman ve Eskicumalı'nın (2006) eğitim programının, hayatta geçerli olan ve işe yarayan konuları içermesine yani işlevsel olmasına ilişkin görüşleri ile ortaya çıkmaktadır. Bununla birlikte eğitim programının işlevsel yanı çağdaş eğitim felsefelerinde yer alan, öğrencilerin ilgi ve ihtiyaçlarına dayanan bir program anlayışının benimsenmesi ile ön plana çıkmıştır. Özellikle ilerlemeci felsefeyi esas alan eğitim programlarının odak noktası; öğrencilerin bireysel özellikleri, deneyimleri, ilgi ve ihtiyaçlarıdır (Gutek, 2014).

Ayrıca öğretmenlerin eğitim programına ilişkin görüşlerinin olumlu yönde olduğu da yapılan tanımlardan anlaşılmaktadır. Öğretmenlerin sahip oldukları bilgi, beceri ve inançlar, programın uygulama boyutunda neyin, ne kadar ve nasıl yansıtılacağı veya yansıtılmayacağı hususunda belirleyici faktörler olarak alan yazında vurgulanmaktadır (Bay, Gündoğdu, Ozan, Dilekçi ve Özdemir, 2012; Çakıroğlu, ve Çakıroğlu, 2003; Eren, 2010; Hasweh, 2003). Buradan hareketle, öğretmenler tarafından ortaya konulan bu olumlu bakış açısının program geliştirme çalışmaları kadar eğitim programının uygulanma sürecine de olumlu yönde etki etmesi muhtemeldir. Diğer bir yandan, Aykaç ve Çelik (2014) ile Taşdemir ve Taşdemir (2011) tarafından yürütülen araştırmaların sonucunda, öğretmen ve öğretmen adaylarının ilköğretim programlarına ilişkin olumsuz metaforlar ürettikleri belirtilmiştir. Sonuçlar arasındaki farklılığın, bu araştırma kapsamında görüşlerine başvurulan öğretmenlerin program geliştirme faaliyetlerinde doğrudan görev almaları ile ilişkili olduğu düşünülmektedir. Bu araştırmanın çalışma grubunda yer alan öğretmenlerin tümü program geliştirme faaliyetlerinde görev alarak eğitim programının geliştirilmesinde rol oynamıştır. Bu durumun, öğretmenlerin geliştirilen programı benimsemelerine ve olumlu tutumlar geliştirmelerine neden olduğu düşünülmektedir.

Araştırmaya katılan öğretmenler tarafından eğitim programının öğeleri; hedefler, içerik, eğitim durumları, sınama durumları ve kapsayıcı açıklamalar olarak ifade edilmiştir. Öğretmenlerin eğitim programının öğelerine ilişkin olarak ortaya koydukları görüşler alan yazında yer alan "hedefler, içerik, eğitim durumları ve sınama durumları" öğeleri (Demirel, 2014; Ertürk, 2013; Varış, 1978; Oliva, 2009) ile uyumludur. Buradan hareketle, öğretmenlerin eğitim programının öğelerine ilişkin farkındalıkları olmakla birlikte; bu öğelerle ilgili kuramsal bilgi birikimlerinin yetersiz olduğu sonucuna ulaşılabilir. Yapılan görüşmelerden elde edilen bulgularda eğitim programının öğelerine ilişkin olarak tespit edilen kavram yanılgıları bu 
sonucu destekler niteliktedir. Örneğin bazı öğretmenler amaç, hedef ve kazanım kavramlarını bazıları ise konu, içerik ve ders kavramlarını birbirlerinin yerine kullanılmaktadır. Programın öğelerine ilişkin kavram yanılgılarını ortaya koyan bir diğer husus ise; bir öğretmen tarafından içerik öğesine göre hedeflerin belirlendiğine ilişkin görüştür. Ayrıca bazı öğretmenlerin ise eğitim durumları öğesini "yöntem ve teknikler" ile sınırlandırılmış bir yaklaşımla ele aldıkları da tespit edilmiştir. Bu bağlamda, araştırmaya katılan mesleki ve teknik eğitim öğretmenlerinin eğitim programının öğeleri ile ilgili bilgi ve farkındalık düzeylerinin yeterli olmadığı sonucuna ulaşılabilir. Alan yazında da öğretmenlerin ve öğretmen adaylarının program geliştirme, program okuryazarlık düzeylerine ilişkin olarak yürütülen araştırmalarda benzer sonuçlar elde edilmiştir (Küçüktepe, 2013; Sağ ve Sezer 2012; Türk Eğitim Derneği [TED], 2009; UluçınarSağır ve Karamustafaoğlu, 2011). Öğretmenlerin eğitim programının öğelerine ilişkin bilgi ve farkındalık düzeylerinin yeterli olmaması programların planlandığı gibi uygulamaya yansıtılmasında sorunlar yatabilir. Akınoğlu ve Doğan (2012) eğitim programlarının planlandığ gibi uygulamaya yansıtılabilmesi için gerekli ön koşullardan biri olarak öğretmenlerin programın doğasına, kapsamına ve özelliklerine hâkim olması ve bu çerçevede öğrenmeöğretme sürecini planlaması gerektiğini belirtmişlerdir.

Mesleki ve teknik eğitim öğretmenlerinin eğitim programının işlevlerine ilişkin elde edilen bulgularda, öğretmenler eğitim programına, öğretmen, öğrenci, toplum ve konu alanı olmak üzere farklı bağlamlarda işlevler yüklemişlerdir. Eğitim programının işlevlerine ilişkin olarak araştırmadan elde edilen bu sonuçlar genel olarak Stabback (2016) tarafından hazırlanan UNESCO raporunda vurgulanan eğitim programının, öğrencileri eğitim-öğretim sistemi içinde bilgilendirerek cesaretlendirmenin yanı sıra, birtakım beceriler kazandırması, öğretmen için iyi bir rehber olması, öğretmenin mesleki gelişimini desteklemesi gibi birçok farklı işlevine değinmesi ile benzerlik göstermektedir. Araştırmaya katılan öğretmenler tarafından eğitim programının toplumsal işlevleri olarak ifade edilen toplum tarafından kabul gören norm ve değerlerin öğrencilere aktarılması yoluyla toplumsal düzenin devamının sağlanmasına ilişkin görüşlerinin kuramsal bir bilgi birikimi ve bakış açısı gerektirdiği düşünülmektedir. Öğretmen görüşlerinin kuramsal temelleri Varış (1978) tarafından ifade edilen sosyal olgularla desteklenebilir niteliktedir. Varış (1978) programın toplumsal işlevlerini, toplumun birikmiş muhtevasının öğrencilere aktarılması, kültürün tanıtılması ile birlikte devamının ve gelişmesinin sağlanması şeklinde toplumsal açılardan ifade etmiştir. Bu araştırmada öğretmenler tarafindan eğitim programının toplumsal işlevleri olarak ele alınan, ekonomik kalkınmaya özgü nitelikler de benzer ifadelerle Varış (1978) tarafından insan gücü ve kalkınma ilişkisi çerçevesinde ele alınmıştır. Öte yandan Hesapçığlu (1994), İşman ve Cumalı (2006) eğitim programının, toplumun benimsediği milli ve manevi değerlerin öğrencilere aktarılmasında bir araç görevinde bulunduğunu ifade etmektedirler. Oliva ve Gordon (2012, çev. Tican-Başaran, 2018) ise program geliştirmede ihtiyaç kategorilerine dair yaptığı sınıflandırmada toplumsal ihtiyaç kategorilerine değinmiş ve eğitim programının bu ihtiyaçları gidermede işlev gördüğünü belirtmiştir. Bu işlevin yerine getirilmesinde program geliştirme uzmanlarının toplumun ihtiyaç türlerini dikkate almaları gerekmektedir. Bu ihtiyaç türleri arasında yer alan; sosyal, ekonomik, ahlaki ve manevi ihtiyaç türleri araştırma kapsamında öğretmenler tarafından eğitim programının işlevleri olarak vurgulanmıştır.

Öğretmenler tarafından vurgulanan bir diğer nokta ise, eğitim programının mesleki yükümlülükte adil dağılım sağlama açısından işlev görmesidir. Araştırmaya katılan 
öğretmenlerin bu yöndeki görüşleri ile Aykaç ve Aydın (2006) tarafından eğitim programın, ortak amaçların gerçekleşmesini ve ülkedeki aynı eğitim basamağında yapılan eğitim-öğretim faaliyetlerindeki standardın yakalanmasını sağladığı yönündeki görüşleri ile benzer doğrultudadır. Aykaç ve Aydın (2006) söz konusu ortaklığı eğitim-öğretim faaliyetlerinde standardın yakalanmasına olan etkisi ile ele almaktadır. Eğitimin ülke genelinde ortak bir tabanda yürütülmesi, programın öğrenci ve toplum açısından da önemli bir işlevi olabilirken öğretmenler tarafından bu ortaklık, eğitim programının, öğretmenlere sağladığı birtakım yararlar olarak ifade edilmiştir. Araştırmadan elde edilen bu sonuçlar ışı̆̆ında, öğretmenler tarafından eğitim programının işlevlerine yönelik olarak yapılan açıklamalar, kuramsal alan yazınla örtüşmekle beraber, öğretmenlerin kuramsal alan yazında yer alan işlevler dışında farklı işlevlere de değindikleri görülmüştür. Bu durum, mesleki ve teknik eğitim programlarının kendine özgü yapısından kaynaklanabilir.

Ayrıca, eğitim programının öğrenci açısından işlevlerinden biri olarak araştırmaya katılan öğretmenler tarafından sıklıkla vurgulanan mesleki yeterlilikler, Ata (2007) tarafından MEGEP projesi kapsamında hazırlanan bilişim teknolojileri alanı eğitim programının öğretmen ve öğrenci görüşleri doğrultusunda değerlendirilmesini amaçlayan araştırma bulgusu ile benzerlik göstermektedir. Söz konusu araştırmaya katılan öğretmenlerin tamamına yakını eğitim programının öğrencileri istihdama hazırlama da yeterli olduğunu belirtmişlerdir. Ayrıca, mesleki ve teknik eğitim programlarının "Programla İlgili Genel Bilgiler" başlığı altında programın "sektör beklentilerine cevap veren, ulusal ve uluslararası bilgi, beceri ve yetkinliklere sahip meslek elemanları yetiştirecek" şekilde geliştirildiğine yer verilmesi, programın öğrenciye ilişkin işlevlerinden biri olarak öğretmenler tarafından ifade edilen mesleki yeterlilikler işlevi ile de örtüşmektedir. $\mathrm{Bu}$ bağlamda, araştırmaya katılan öğretmenlerin eğitim programının işlevlerine ilişkin sahip oldukları bilgi birikimlerinin, program geliştirme faaliyetlerinde doğrudan görev almaları ve geliştirilen programı benimsemeleri ile ilişkili olduğu düşünülmektedir.

Mesleki ve teknik eğitimde program geliştirme çalışmalarında görev alan öğretmenlerin eğitim programına ilişkin görüşlerini incelemek amacıyla yapılan bu araştırmada;

- Öğretmenler, eğitim programı kavramını alan yazında kabul gören birçok kuramsal noktaya vurgu yaparak tanımlamışlardır. Bu tanımlardan hareketle, araştırmaya katılan öğretmenlerin ağırlıklı olarak geleneksel program anlayışına ilişkin kuramsal düzeyde belli bir bilgi birikimi ve farkındalı̆ga sahip oldukları sonucuna ulaşılabilir.

- Öğretmenlerin eğitim programının öğeleri ile ilgili birtakım eksik ve hatalı bilgilere sahip olduğu tespit edilmiştir. Bu eksiklikler özellikle "hedef" "içerik" "eğitim durumları" öğeleri etrafında yoğunlaşmaktadır. Bu durumun amaçlanan program ile uygulanan program arasında farklılıklara neden olabileceği düşünülmektedir.

- Öğretmenlerin eğitim programının işlevlerine yönelik görüşleri, alan yazınla örtüşmekle beraber, alan yazında yer alan işlevler dışında farklı işlevlere de değindikleri görülmüştür. Bu durumun, mesleki ve teknik eğitim programlarının kendine has yapısı ve eğitim-öğretim sistemi içinde meslek edindirme amac1, öğretmenlerin program geliştirme çalışmalarından elde ettikleri deneyimlerle ilişkili olduğu düşünülmektedir. 
Sonuç olarak, araştırmaya katılan mesleki ve teknik eğitim öğretmenlerinin eğitim programına ilişkin sahip oldukları bilgi birikimi, farkındalık düzeyleri ve olumlu bakış açıları göz önüne alındığında, program geliştirme çalışmalarında öğretmen katılımının gerekliliği ve önemi oldukça açıktır. Bu bağlamda, program geliştirme sürecinin her aşamasında öğretmen katılımının nitelik ve nicelik açısından yeterli düzeyde gerçekleştirilmesi önerilmektedir. Buna ek olarak, araştırmaya katılan mesleki ve teknik eğitim öğretmenlerinin program geliştirmeye yönelik olarak aldıkları hizmet içi eğitim ve sonrasında görev yaptıkları program geliştirme çalışmalarında elde ettikleri deneyimlere rağmen, bazı kavram ve uygulamalarda yeterli düzeyde bilgiye sahip olmadıkları tespit edilmiştir. $\mathrm{Bu}$ durumun program geliştirme çalışmalarında görev almayan öğretmenlerde de benzer veya daha üst düzeyde olması muhtemeldir. $\mathrm{Bu}$ nedenle öğretmenlere ihtiyaçları doğrultusunda program geliştirmenin kuramsal temellerine ilişkin hizmet içi eğitimler sunulması önerilmektedir. 


\section{Kaynakça}

Akınoğlu, O. ve Doğan, S. (2012). Eğitimde program geliştirme alanına yeni bir kavram önerisi: Program okuryazarlı̆̆l. 21. Ulusal Eğitim Bilimleri Kongresi, 12-14 Eylül 2012, Marmara Üniversitesi, İstanbul.

Aktaş, M. (2012). Metal teknolojisi öğretmenlerinin mesleki ve teknik ortaöğretim kurumlarında uygulanan metal teknolojisi alanı modüler öğretim programı hakkında görüşleri: Antalya örneği. Yayımlanmamış yüksek lisans tezi, Akdeniz Üniversitesi Sosyal Bilimler Enstitüsü, Antalya.

Alkan, C., Doğan, H. ve Sezgin, İ. (1998). Mesleki ve teknik ĕgitimin esasları. Ankara: Alkım Yayınları.

Altunışık, R., Coşkun, R., Bayraktaroğlu, S., ve Yıldırım, E. (2017). Sosyal bilimlerde araştırma yöntemleri: SPSS uygulamalı (9.Baskı). Sakarya: Sakarya Yayıncılık.

Arabacıoğlu, T. (2013). Bilişim teknolojisi öğretmenlerinin modüler eğitim programına ilişkin görüşleri: Aydın ilinde bir durum çalışması. Ilköğretim Online, 12(1), 148-157.

Ata, U. (2007). Mesleki teknik ĕgitim ve MEGEP öğretim programlarına ögrenci ve ögretmen yaklaşımları (Bilişim Teknolojileri Alanında uygulama). Yayımlanmamış yüksek lisans tezi, Beykent Üniversitesi Sosyal Bilimler Enstitüsü, Ankara.

Aykaç, N. ve Aydın, H. (2006). Öğrenme öğretme sürecinde planlama ve uygulama. Ankara: Natürel Yayıncilık.

Aykaç, N., ve Çelik, Ö. (2014). Öğretmenlerin ve öğretmen adaylarının eğitim programına ilişkin metaforik algılarının karşılaştırılması. Eğitim ve Bilim, 39(173), 328-340.

Bay, E. Gündoğdu, K., Ozan, C., Dilekçi, D. ve Özdemir, D. (2012). İlköğretim öğretmen adaylarının program yaklaşımlarının analizi. Uluslararası Eğitim Programları ve Öğretim Çalışmaları Dergisi, 2(3), 15-29.

Bümen, N. T. ve Aktan, S. (2014). Yeniden kavramsallaştırma akımı ışığında Türkiye'de eğitim programları ve öğretim alanı üzerine özeleştirel bir çözümleme. Kastamonu Eğitim Dergisi, 22(3), 1123-1144.

Büyüköztürk Ş., Kılıç-Çakmak E., Akgün Ö.E., Karadeniz Ş. ve Demirel F. (2014). Bilimsel araştırma yöntemleri (17. Baskı). Ankara: Pegem A

CEDEFOP. (2008). Terminology of European education and training policy a selection of 100 key terms. Ocak $2017 \quad$ tarihinde htp:/www.cedefop.europa.eu/en/publications-andresources/publications/4064 adresinden erişildi.

Creswell, J. W. (2014). Araştırma deseni-nitel, nicel ve karma yöntem yaklaşımları (S. B. Demir, Çev. Edt.). Ankara: Eğiten Kitap Yayınları.

Çakıroğlu, E. ve Çakıroğlu, J. (2003). Reflections on teacher education in Turkey. European Journal of Teacher Education, 26(2), 253-264. 21.

Demirel, Ö. (2014). Eğitimde program geliştirme.(21.Baskı). Ankara: Pegem A.

Duman, E. (2006). Sınıf ögretmeni adaylarının program geliştirme yeterlikleri hakkındaki görüşlerinin belirlenmesi (Ankara Üniversitesi ve Kırıkkale Üniversitesi örnekleri). Yayımlanmamış doktora tezi. Ankara Üniversitesi, Ankara.

Ekşioğlu, S. (2013). Mesleki ve teknik liselerde uygulanan modüler öğretim programının değerlendirilmesi. Yayımlanmamış doktora tezi, Gazi Üniversitesi Eğitim Bilimleri Enstitüsü, Ankara.

Eren, A. (2010). Öğretmen adaylarının program inançlarının görünüm analizi. Kastamonu Eğitim Dergisi, 18(2), 379-388.

Ergin, Ö. (2008). MEGEP kapsamında meslek liselerinin bilişim teknolojileri alanı için geliştirilen ĕgitim programının öğretmen görüşlerine göre değerlendirilmesi. Yayımlanmamış yüksek lisans tezi, Atatürk Üniversitesi Fen Bilimleri Enstitüsü, Erzurum.

Ertürk, S. (2013). Eğitimde program geliştirme. (6. Bask1). Ankara: Yelkentepe. 
ETF. (2005) Glossary of vocational education, training (VET) and labour market terms. Turkish Employment Agency (ISKUR). ETF National Observatory in Turkey. ETF Working paper.

Gutek, G. L. (2014). Eğitime felsefi ve ideolojik yaklaşımlar. (N. Kale, Çev.). Ankara: Ütopya Yayınları Hasweh, M. Z. (2003). Teacher accommodative change. Teaching and Teacher Education, 19, 421-434. Hesapçıŏlu, M. (1994). Öğretim ilke ve yöntemleri: Eğitim programları ve ögrretim. (4. Baskı). İstanbul: Beta Basım Yayım Dağıtım.

ILO, (2006). Strategies and practices for labour inspection. ILO Governing Body, November. Geneva İşman, A. ve Eskicumalı, A. (2006). Öğretimde planlama ve değerlendirme. Ankara: Sempati Yayıncılık. İşoğlu, İ. V. (2010). MEGEP bilişsim teknolojileri alanı modüllerinin öğretmen görüşleriyle değerlendirilmesi. Yayımlanmamış yüksek lisans tezi, Marmara Üniversitesi Eğitim Bilimleri Enstitüsü.

Küçüktepe, C. (2013). Sınıf öğretmenlerinin hizmet içi eğitim ihtiyaçlarının öğretmen görüşlerine göre belirlenmesi, Abant İzzet Baysal Üniversitesi Eğitim Fakültesi Dergisi, 13(2), 26-43.

MEB, (2017). Müfredatta yenileme ve değişiklik çalışmalarımız üzerine. Şubat 2019 tarihinde https://ttkb.meb.gov.tr/meb_iys_dosyalar/2017 07/18160003 basin_aciklamasi-program.pdf adresinden erişildi.

METARGEM. (1997). Endüstri meslek lisesi mezunlarını izleme araştırmasl. Ankara: Millî Eğitim Basımevi.

MTEGM. (2013).Mesleki ve teknik öğretim programları ve materyalleri geliştirme usul ve esaslarl. Ankara: Yazar

MTEGM. (2014). Strateji belgesi, Türkiye mesleki ve teknik eğitim strateji belgesi ve eylem planı 20142018. Şubat 2017 tarihinde http://abdigm.meb.gov.tr/ projeler/ois/017.pdf adresinden erişildi.

Oliva, P. F. (2009). Developing the curriculum. New York: Pearson Allyn and Bacon.

Oliva, P., F. \& Gordon, W., R. (2018). Veriye dayalı karar verme. (Tican-Başaran, S., çev.). K.Gündoğdu, (Ed). Program geliştirme içinde (211-240). Ankara: Pegem.

Ornstein, A. C. \& Hunkins, F. P. (2004). Curriculum: Foundations, principles and issues. US: Pearson

Sağ, R. ve Sezer, R. (2012). Birleştirilmiş sınıf öğretmenlerinin mesleki eğitim ihtiyaçları, İlköğretim Online, 11(2), 491-503.

Seçilmiş, C. ve Ünlüören, K. (2010). Anadolu otelcilik ve turizm meslek liselerinde uygulanan modüler öğretime ilişkin öğretmen görüşlerinin değerlendirilmesi. Ahi Evran Üniversitesi Kırşehir Eğitim Fakültesi Dergisi, 11(2), 247-265.

Stabback, P. (2016). What makes a quality curriculum. Current and critical issues in the curriculum and learning. IBE-UNESCO, Retrieved from http://unesdoc.unesco.org/images/0024/002439/ 243975e.pdf

Tan-Şişman, G. ve Karsantık, Y. (2017). An investigation of the curriculum development process in Singapore and Turkey regarding administrative structure and reforms [Singapur ve Türkiye'de program geliştirme süreçlerinin yönetsel yapı ve reformlar açısından incelenmesi]. 26.Uluslararası Eğitim Bilimleri Kongresi. Antalya, 20-23 Nisan, 2017. Ocak 2018 tarihinde http://2017.ices-uebk.org/dosyalar/files/ices2017 ozetkitabi_v1.pdf adresinden erişildi.

Taşdemir, M. ve Taşdemir, A. (2011). İlköğretim programı üzerine öğretmen metaforları. $2^{\text {nd }}$ International Conference on New Trends in Education and Their Implications. (795-809). Antalya-Türkiye.

Tekbıyık, A., ve Akdeniz, A. R. (2008). İlköğretim fen ve teknoloji dersi öğretim programını kabullenmeye ve uygulamaya yönelik öğretmen görüşleri. Necatibey Ĕgitim Fakültesi Elektronik Fen ve Matematik Eğitimi Dergisi, 2(2). 23 - 37.

Tutkun, Ö. F. ve Aksoyalp, Y. (2010). 21. yüzyılda eğitimde program geliştirmede yönelim, kavram ve anlayışlar. Sakarya Üniversitesi Eğitim Fakültesi Dergisi, 19, 156-169

Türk Eğitim Derneği [TED], (2009). Öğretmen yeterlikleri. Ankara: Türk Eğitim Derneği 
Türkeşsiz, S. (2008). MEGEP kapsamında motorlu araçlar teknolojisi alanı öğretim programlarının mevcut meslek liselerinde uygulanabilirlik düzeyinin araştırılması. Yayımlanmamış yüksek lisans tezi, Afyon Kocatepe Üniversitesi Fen Bilimleri Enstitüsü, Afyon.

Uluçınar-Sağır, Ş. ve Karamustafaoğlu, O. (2011). Fen bilgisi öğretmen adaylarının program geliştirme sürecine ilişkin bilgi düzeyleri. Celal Bayar Üniversitesi Eğitim Fakültesi Dergisi, 1(1), 109-123

UNESCO. (1996). Financing technical and vocational education: Modalities and experiences; UNESCO ED/IUG/006. Berlin, 1-62.

Unruh, G. G. \& Unruh, A. (1984). Curriculum development, problems, process and progress. California: McCutchan Publishing Carparation.

Varış, F. (1978). Eğitimde program geliştirme "teori ve teknikler" (3. Baskı). Ankara: Ankara Üniversitesi Basımevi.

Yıldırım, A. ve H. Şimşek (2001). Türkiye'de meslek liselerinde program geliştirme sürecinin nitel bir analizi (A Qualitative Assessment of Curriculum Development Process at Secondary Vocational Schools in Turkey) Journal of Career and Technical Education, 18(1), 19-31.

Yıldırım, A. ve Şimşek, H. (2013). Sosyal bilimlerde nitel araştırma yöntemleri (Genişletilmiş 9. Baskı). Ankara: Seçkin Yayıncılık.

Yılmaz, H. ve Yiğit, N. (2011). Fen ve teknoloji dersi 6. sınıf öğretim programına yönelik öğrenci görüş ve beklentileri. Milli Ĕgitim Dergisi, 40(190), 269-292.

Yiğit, N. (2002). Öğretim programları geliştirmede öğretmenin rolü. Çağdaş Eğitim Dergisi, 296, 27-33. 


\section{Extended Abstract}

\section{Introduction}

Technical and vocational education is one of the key drivers for socio-economic growth and development of a country. Focusing on practical training for the development of skills required by the chosen occupation and related theory, technical and vocational education is the type of education aiming to equip students with knowledge and skills needed to become highly skilled workers for industry and other services required by society. In order to bring purpose to life and gain functionality, curriculum and teachers are seen as critical aspects of technical and vocational education process. There is no doubt that qualifications of teachers related to curriculum development process are closely related to the quality of education. Thus, there have been calls for research to portray teachers' views about curriculum. In this respect, the purpose of the study was to investigate the theoretical and practical aspects of curriculum through the views of the teachers who took part in the curriculum development commissions as well as working at the public vocational-technical high schools located in Ankara. In this regard, the following research questions guide the study (1) How do the teachers define curriculum? (2) What are the teachers' views about the aspects of the curriculum? and (3) What are the teachers' views about the functions of curriculum?

\section{Methodology}

The study has a qualitative research design, adopting the phenomenology pattern. The participants were selected through criterion and maximum variation sampling strategies that assist to the selection of relevant and rich data sources for the study. The participants were determined with respect to the following criteria: the teachers who took part in the Curriculum Development Commissions in the years between 2012-2016 held by the General Directorate of Vocational and Technical Education as well as working at the public vocational-technical high schools located in Ankara. Among 34 teachers who met the criteria, 19 of them voluntarily accepted to participate in the study. The data gathered through semi-structured interview schedule developed by the researchers and analyzed through content analysis.

\section{Findings}

The findings indicated that the teachers provided the six main themes for the concept of curriculum as guide, official document, evolving document, framework, functional document and system. While all of the teachers defined curriculum as a guideline for educational and instructional activities, some stated curriculum as a framework providing flexibility within certain boundaries for the teachers. Additionally, some of the teachers described curriculum as constantly evolving dynamic structure depending on current information as well as a functional document that consists of the information and skills are needed by students and the society. Further, some teachers conceptualized curriculum as a systematic structure in terms of input, process, output and context by emphasizing the part-whole relation.

Furthermore, the findings about the aspects of curriculum indicated that aim/objectives, content, teaching and learning process, measurement and evaluation and comprehensive explanations were the main aspects of curriculum. Among them, content was the mostemphasized aspect of curriculum following aims/objectives. According to the teachers, while 
the aspect of teaching and learning process were related to such instructional issues as methods, techniques, tools and educational environment; the aspect of measurement and evaluation were related to assessment of the levels of student performance and achievement. Another aspect of curriculum emphasized by the teachers was comprehensive explanations. The teachers stated that curriculum should be included examples, warnings and explanations shed light on the implementation process for inspectors, school administrators and teachers. Lastly, the results indicated that some teachers used such terms as aim and objective and interchangeably and they conceptualized teaching and learning process within the scope of instructional methods and techniques.

Considering the functions of curriculum, the teachers attributed diverse functions to curriculum in terms of teachers, students, society, and subject area. The main functions of curriculum for teachers were guiding for instruction, providing continuity in professional development, making fair distribution in professional obligation, providing legal basis for profession. In terms of students, curriculum was seen to have three basic functions as assisting learning process, equipping students with vocational qualifications and providing integration with society. In addition, the teachers also pointed that providing continuity of social order and assisting economic development were the functions of curriculum for the society. In terms of subject area, curriculum has two functions as updating and systematization.

\section{Conclusion}

The findings revealed that the vocational and technical education teachers defined curriculum as a guideline for educational and instructional activities. Although they revealed some awareness about the theoretical and practical issues of curriculum, some of them have inadequate knowledge about the concept of curriculum. It can be concluded that the teachers' definitions regarding the concept of curriculum is mainly based on traditional understanding of curriculum. Besides, some functions attributed to curriculum by the teacher are in line with literature, some of them are different. So, this differentiation can be interpreted as a reflection of the unique structure of vocational and technical education and the experiences gained during the curriculum development process. Nevertheless, some of the teachers lacked adequate theoretical knowledge regarding the aspects of curriculum. Taking all findings into account, it is obvious that the teachers' role as a member of the curriculum development process is crucial both for teachers' professional development and the curriculum development process in vocational and technical education. 